\title{
Connecting research, management, education and policy for the conservation of armadillos in the Orinoco Llanos of Colombia
}

\author{
Mariella Superina, Alexandra Cortés Duarte and Fernando Trujilo
}

\begin{abstract}
Successful conservation actions require strategies that combine research, policy formulation and enforcement, practical interventions and education. Here we review the Armadillo Conservation Programme, which was initiated in 2012 as a pioneering multidisciplinary programme for the conservation and management of five armadillo species in the Orinoco Llanos of Colombia. It is led by a multi-institutional alliance that ensures active participation of stakeholders during all stages of the programme. Six main threats affecting armadillo populations in the Llanos were identified, and these were addressed in the first joint action plan of two Colombian environmental authorities. Scientific research facilitated an increase in the knowledge available about the armadillos of the Llanos, and the recategorization of the northern longnosed armadillo Dasypus sabanicola on the IUCN Red List. Threat evaluation and mitigation included the assessment of illegal bushmeat trade and consumption in local restaurants and the establishment of a certification label for restaurants that do not sell wild meat. Multiple strategies were used to raise awareness about armadillos and position them as flagship species for the Llanos, including education programmes in schools, travelling exhibitions, talks at universities, and the publication of several books. The local communities were actively involved through a network of private reserves committed to the conservation of armadillos, in which armadillos are protected from poaching and monitored by farmers. Breeding and rehabilitation facilities were established that can host confiscated armadillos and raise awareness among the local communities. This case study shows that conservation programmes targeted at inconspicuous and poorly known species can be successful.
\end{abstract}

\footnotetext{
MARIELla SuPERINA ${ }^{*}$ (Corresponding author) Laboratorio de Medicina y Endocrinología de la Fauna Silvestre, Instituto de Medicina y Biología Experimental de Cuyo, Centro Científico Tecnológico, Consejo Nacional de Investigaciones Científicas y Técnicas, Mendoza, Argentina

E-mailmsuperina@mendoza-conicet.gov.ar

Alexandra Cortés Duarte* and Fernando Trujlllo* Fundación Omacha, Bogotá, Colombia

*Also at: Alianza Oleoducto de los Llanos Orientales, Fundación Omacha, Cormacarena, Corporinoquia, Corpometa, Bioparque Los Ocarros, Colombia †Also at: Fundación Omacha, Bogotá, Colombia

Received 6 December 2017. Revision requested 16 April 2018.

Accepted 22 May 2018. First published online 12 November 2018.
}

Keywords Action plan, armadillo, Chlamyphoridae, Cingulata, Colombia, Dasypodidae, wildlife conservation

\section{Introduction}

Successful conservation actions require strategies that $\checkmark$ combine research, policy formulation and enforcement, practical interventions and education (Sutherland, 2000). To increase the chances of achieving sustained conservation outcomes, stakeholders, including the local population and industry, should be involved in all stages, from development and planning to execution and monitoring (Reed, 2008).

Armadillos (Xenarthra: Cingulata) are semi-fossorial mammals restricted to the Americas, and they have long been neglected by the scientific community. According to the IUCN Red List, of the 20 extant armadillo species, two are categorized as Vulnerable, five as Near Threatened and five as Data Deficient (IUCN, 2017). The development of conservation plans for armadillos is hindered by the scarcity of scientific information on their ecology, reproductive strategies, and threats to their survival (Superina et al., 2014b).

The situation is especially critical in the Orinoco Llanos region of eastern Colombia, which is inhabited by five armadillo species: the southern naked-tailed armadillo Cabassous unicinctus, the nine-banded armadillo Dasypus novemcinctus, the greater long-nosed armadillo Dasypus kappleri, the northern long-nosed armadillo Dasypus sabanicola and the giant armadillo Priodontes maximus. The conservation status of the first three has not been assessed at the national level; D. sabanicola is categorized as Data Deficient and P. maximus as Vulnerable on the national red list (Rodríguez-Mahecha et al., 2006).

Deforestation rates in the Orinoco Llanos are among the highest in Colombia (Instituto de Hidrología, Meteorología y Estudios Ambientales, 2016). This is related to the rapid expansion of agroindustrial activities, especially the production of biofuel, timber and cash crops (Lasso et al., 2011). It is estimated that c. $10 \%$ of the natural habitat in the Orinoco Llanos is affected by land-use change every year. A 10 -fold increase in the area used for agricultural activities, especially for oil palm, rice, timber, soy and corn plantations, has been projected until 2020 (Aristizábal et al., 2000; Dishington, 2007; Fedearroz, 2008; Fedepalma, 2008; Instituto 
Alexander von Humboldt, 2009; CRECE, 2010). In addition, oil extraction has increased significantly in the Orinoco Llanos since 2000 and accounts for $90 \%$ of the national oil production (Correa et al., 2006; Bayona, 2012). All these activities lead to degradation and fragmentation of wildlife habitat. Associated demographic shifts, such as the migration of workers from urban areas and transformation of farms to oil fields, have led to cultural changes that directly or indirectly affect wildlife (Correa et al., 2006).

Inspired by Garnett \& Lindenmayer (2011), who advocated disseminating conservation success stories to engender positive thinking and counterbalance pessimistic reports about biodiversity loss, we review a pioneering pilot programme for the conservation of armadillos in the Llanos of Colombia that could be replicated in other areas and applied to other species.

\section{Study area}

The Armadillo Conservation Programme focused initially on the area of influence of the $235 \mathrm{~km}$ Oleoducto de los Llanos pipeline, which runs from the Rubiales oilfield (Meta department) to Monterrey (Casanare department) in the Orinoco Llanos region of Colombia (Fig. 1). In its second year, the programme was expanded to the entire departments of Casanare, Arauca, Vichada and Meta, to cover the complete areas of jurisdiction of the environmental agencies Corporinoquia and Cormacarena, encompassing an area of almost $260,000 \mathrm{~km}^{2}$.

The area is part of the binational basin of the Orinoco River, which in Colombia includes the Meta River basin (Correa et al., 2006). The landscape is dominated by seasonal tropical savannah, which is characterized by extensive, seasonally flooded savannahs, gallery forests and riparian forests (Hernández-Camacho \& Sánchez, 1992). The current population of c. 1,650,000 inhabitants (Departamento Administrativo Nacional de Estadística, 2017) consists of four socio-cultural groups, each of which maintains its cultural, geographical and historical characteristics: Indigenous Peoples, consisting of 14 distinct ethnic Indigenous groups; native farmers of the Llanos, mainly dedicated to cattle ranching; native farmers of the Andes, mainly dedicated to agricultural activities; and settlers originating from other areas of Colombia, who are primarily employed in extractive industries (Sánchez, 2007).

\section{The Armadillo Conservation Programme}

Institutions involved

The Conservation and Management Programme for the Armadillos of the Llanos of Colombia (Armadillo
Conservation Programme) primarily involves six institutions: Oleoducto de los Llanos Orientales, a Colombian private company managing a pipeline in the Orinoco region; Fundación Omacha, a Colombian NGO dedicated to biodiversity research and conservation; the environmental agencies Corporinoquia and Cormacarena, whose jurisdictions enclose the departments of Casanare, Arauca and Vichada, and Meta department, respectively; Bioparque Los Ocarros, a zoological institution dedicated to native wildlife of the Llanos; and Corpometa, a company that promotes the social and economical development of Meta department. Other stakeholders, including the local communities and educational institutions, participate in specific projects.

\section{Diagnosis of the most relevant problems}

A diagnosis was made of the most relevant problems directly or indirectly affecting the armadillo populations in the Llanos. It involved a literature review, and a threat analysis based on the biodiversity action plan for the Orinoco region (Correa et al., 2006) and other relevant publications (e.g. Dishington, 2007; Fedearroz, 2008; Fedepalma, 2008; Instituto Alexander von Humboldt, 2009; Lasso et al., 2011), as well as consultations with Colombian mammalogists and international armadillo experts over the course of 6 months. In addition, four workshops were held, involving all institutions participating in the Armadillo Conservation Programme and other stakeholders. Six major issues were identified and several parallel and complementary lines of action established (Table 1). Multiple approaches were used to pursue these, as described below.

\section{Development of an action plan}

Four workshops were held and stakeholders interviewed in various parts of the Llanos during November 2012November 2013, to analyse the major threats and drivers associated with landscape transformation, and to identify gaps in information and research needs in relation to armadillos. A working document of the Action Plan was then developed during meetings with staff of the environmental authorities Cormacarena and Corporinoquia. The Armadillo Action Plan was approved in 2014 by resolutions issued by both authorities, laying the foundation for all subsequent actions of the Armadillo Conservation Programme described here. It included a detailed analysis of the threats to the conservation of armadillos in the Orinoco Llanos of Colombia, and seven lines of action (Superina et al., 2014d).

The Armadillo Action Plan was presented to the authorities and other interested persons during workshops held in 44 town halls in the Llanos. The municipalities were invited to participate in its implementation. 


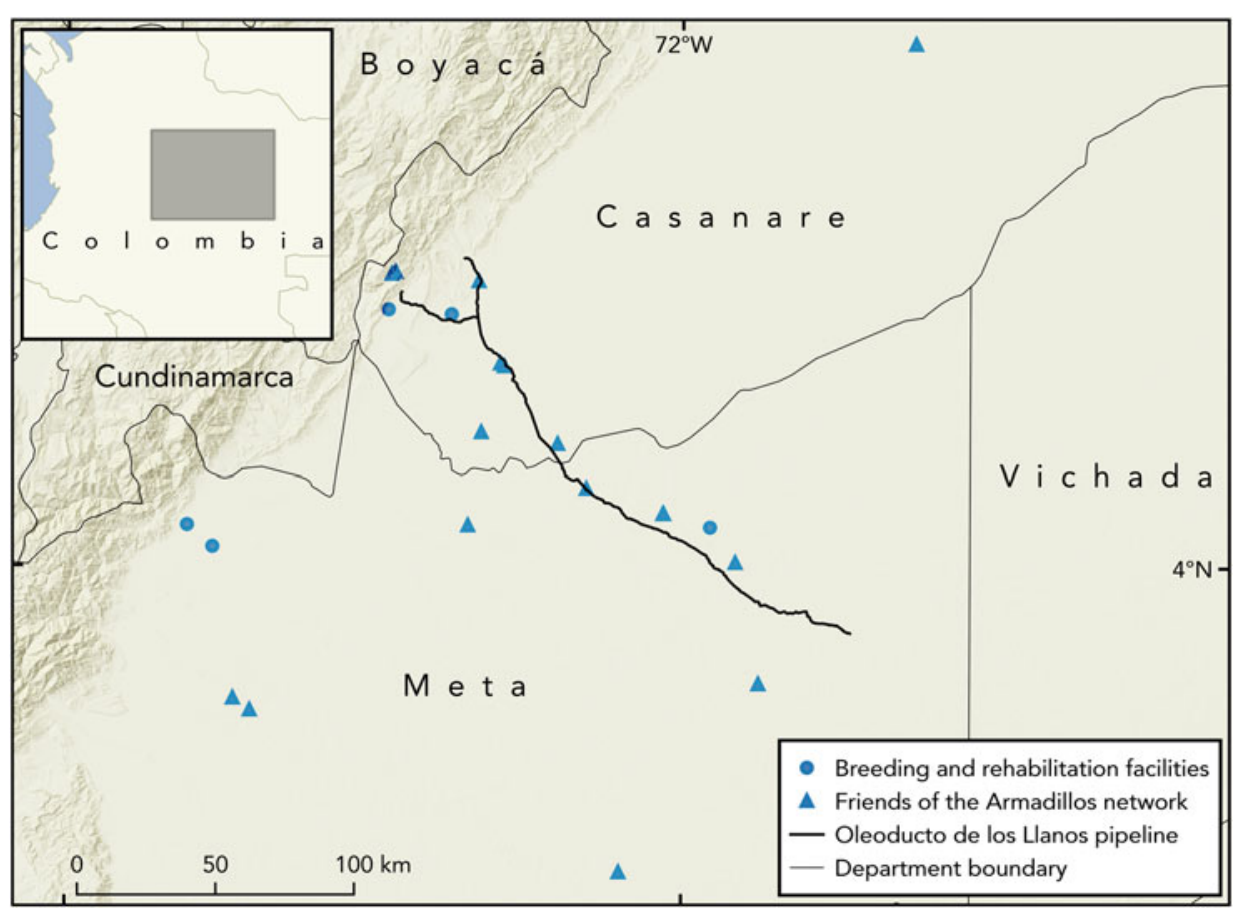

FIg. 1. Target area of the Armadillo Conservation Programme in the Orinoco Llanos region of Colombia.

TABLE 1. Most relevant problems directly or indirectly affecting armadillos in the Orinoco Llanos of Colombia (Fig. 1), their consequences, and the approach used by the Armadillo Conservation Programme to tackle them.

\begin{tabular}{|c|c|c|}
\hline Problem & Consequence & Approach \\
\hline $\begin{array}{l}\text { No legal instruments or tools to protect } \\
\text { armadillos }\end{array}$ & $\begin{array}{l}\text { Armadillos not a conservation priority for } \\
\text { environmental agencies }\end{array}$ & Development of action plan \\
\hline No research being performed on armadillos & $\begin{array}{l}\text { Lack of basic knowledge on local armadillo } \\
\text { populations }\end{array}$ & $\begin{array}{l}\text { Promote research through grants programme } \\
\& \text { talks at universities; hire researchers }\end{array}$ \\
\hline Rapid land-use change & $\begin{array}{l}\text { Multiple threats potentially affecting } \\
\text { armadillos }\end{array}$ & $\begin{array}{l}\text { Assess whether \& how potential threats } \\
\text { affect armadillos; seek ways to mitigate } \\
\text { impact }\end{array}$ \\
\hline $\begin{array}{l}\text { Changes in demographic composition as a } \\
\text { result of movement of people from cities to } \\
\text { the Llanos to work in agroindustrial } \\
\text { activities }\end{array}$ & $\begin{array}{l}\text { Loss of traditional knowledge on wildlife; } \\
\text { lack of awareness of conservation issues }\end{array}$ & Involve local communities \\
\hline $\begin{array}{l}\text { Armadillos not included in education } \\
\text { programmes }\end{array}$ & No awareness among children & Education programmes \\
\hline $\begin{array}{l}\text { Sustained increase in commercial hunting \& } \\
\text { illegal trade }\end{array}$ & $\begin{array}{l}\text { Increased number of confiscations of illegally } \\
\text { captured, injured armadillos; insufficient } \\
\text { institutions to host \& rehabilitate them; lack } \\
\text { of knowledge on ex situ management }\end{array}$ & $\begin{array}{l}\text { Reduction of wild meat trade; establishment } \\
\text { of private rehabilitation facilities; } \\
\text { development of husbandry \& rehabilitation } \\
\text { protocols }\end{array}$ \\
\hline
\end{tabular}

\section{Research grants programme}

A grants programme was established to support field research and conservation work within the study area. Funding was provided by the institutions participating in the Armadillo Conservation Programme. Grantees also received technical and scientific support. Two undergraduate theses and four external research projects were supported by the grants programme. Additional research was performed by programme biologists. Research topics included the ecology, behaviour and genetic diversity of armadillos, and the threats affecting them.

\section{Threat evaluation and mitigation}

Three direct threats were identified in the action plan (Table 2). Research and education strategies were developed to address them.

\section{Poaching, consumption and commercialization of armadillos}

Poaching and illegal trade are considered to be the most important threats to the armadillos of the Llanos. Although subsistence hunting is legal, commercial hunting and selling wild 
TABLE 2. Level of threat associated with direct and indirect factors affecting armadillos in the Orinoco Llanos of Colombia (Fig. 1).

\begin{tabular}{|c|c|c|c|c|c|}
\hline \multirow[b]{2}{*}{ Level of threat } & \multicolumn{3}{|l|}{ Direct } & \multicolumn{2}{|l|}{ Indirect } \\
\hline & Poaching \& illegal trade & Habitat transformation & Road traffic & Reduction of prey & Climate change \\
\hline High & & & & & \\
\hline $\begin{array}{l}\text { Medium } \\
\text { Low }\end{array}$ & & & & & \\
\hline
\end{tabular}

meat are prohibited by law in Colombia. Nevertheless, the latter is increasingly frequent within and near the main towns in Meta and Casanare departments, largely because immigrant workers with high purchasing power are willing to pay USD 15 to eat armadillo meat at restaurants, which is over five times the regular cost of a meal. This high demand, in turn, has caused a shift from subsistence to large-scale commercial hunting, which is affecting the wild armadillo populations.

The magnitude of the wild meat trade was assessed in two major cities of the Llanos, Puerto Gaitán and Puerto López. Local people were interviewed to assess patterns and tendencies of wild meat consumption. Over $90 \%$ of 183 interviewees confirmed they had consumed wild meat at least once. Half of them reported that they regularly ate wild meat, mainly on private farms $(42 \%)$ and less frequently in restaurants (11\%). The most commonly consumed mammal species were lowland pacas Cuniculus paca, capybaras Hydrochoerus hydrochaeris and armadillos. Dasypus sabanicola was preferred over D. novemcinctus, and C. unicinctus and $P$. maximus were consumed only rarely.

Trained local people posing as customers visited restaurants to determine whether they sold wild meat. Of 85 restaurants assessed, 45 (53\%) were selling wild meat illegally, usually discretely and only to known clients, to avoid sanctions. A workshop was held with 40 restaurant owners in the city of Puerto Gaitán (Meta department) with the aim of providing them with tools to increase their revenues without selling illegal products (Table 3). Six of these restaurants joined the Armadillo Conservation Programme's 'Restaurants free of wild meat' programme. Twenty-seven restaurants in Yopal, Tauramena and Monterrey (Casanare department) were visited to inform them about the programme, and 26 of these joined the programme. They will be provided with training in 2018. All participating restaurants received placemats and tabletop signs with various messages about armadillo conservation, as well as a poster certifying their compliance with the programme. As an incentive, their premises are promoted by the environmental and tourism authorities, and featured on their websites. They are monitored regularly by the environmental agencies to ensure ongoing compliance.

\section{Habitat transformation}

Land-use change is thought to affect armadillos directly through habitat loss and indirectly through the increased use of agrochemicals that reduce the availability of insects, their main food source (Redford, 1985; Wickramasinghe et al., 2004; Trujillo \& Superina, 2013). As a first step, the presence, distribution, habitat preference, and seasonal behavioural patterns of various armadillo species were assessed by means of camera traps and transect walks (Rodríguez et al., 2013b), as well as through interviews (Rodríguez Durán et al., unpubl. data). Sightings of D. novemcinctus and C. unicinctus were less frequent than expected. An ecological assessment revealed that $P$. maximus primarily uses riparian forests (Aya-Cuero et al., 2015, 2017) and only rarely ventures into open lands. Dasypus sabanicola was observed mainly in open savannahs and has declined or become extirpated from cultivated areas. Sightings and reports of D. kappleri were rare, and limited to forested areas (Aya-Cuero, 2016).

\section{Impact of road traffic}

Road construction through wildlife habitat, and intense vehicular traffic, especially to and from oil fields, appears to be a significant cause of mortality of wild species. The impact of road traffic on armadillos and other vertebrates was assessed by recording vehicle-wildlife collisions on three major roads of the Llanos. The study revealed that only three of 127 roadkilled vertebrates were armadillos (Vásquez-Ávila et al., unpubl. data). In parallel, awareness was raised among trucking companies and the local population during workshops and by distributing flyers and stickers (Table 3 ).

\section{Involvement of local communities}

The active involvement of the local communities to ensure their long-term commitment was considered to be a key factor in the programme's success. Informal and semistructured interviews about the use, traditions and cultural value of armadillos were held with 67 owners, administrators or workers of farms and private reserves. The findings indicated regional differences in the occurrence of the five armadillo species. In general, the interviewees had basic knowledge about the ecology of the species present in their area. They reported a reduction in wildlife densities, especially of armadillos, over the previous 40 years, which they associated with the expansion of human activities.

The Friends of the Armadillos programme was then established to build up a network of farms and private natural 


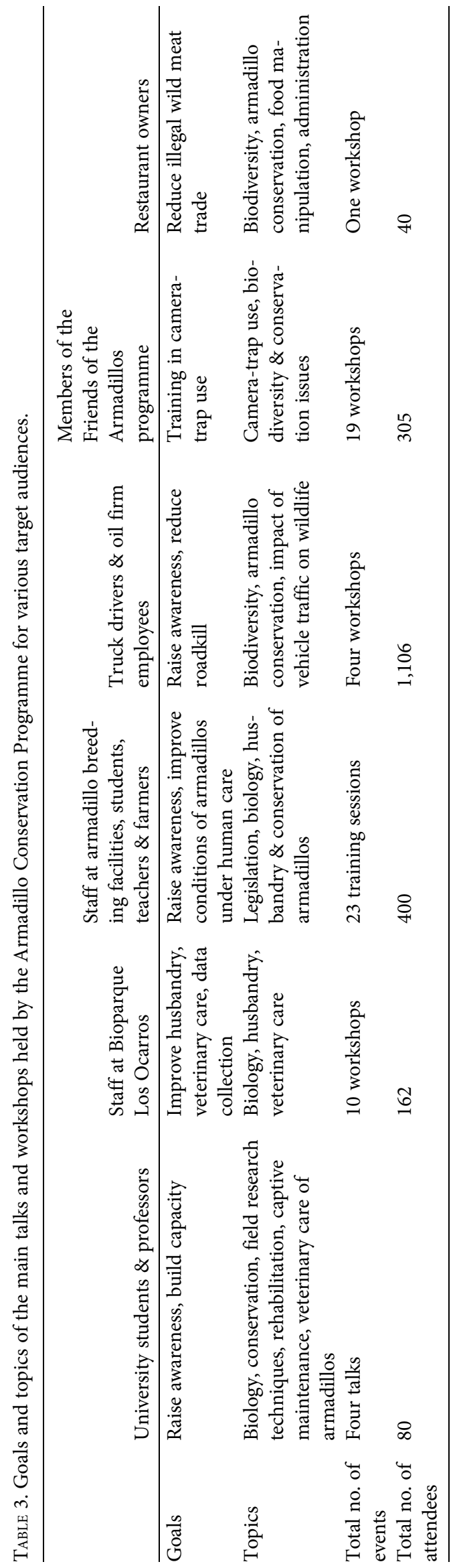

reserves committed to the conservation of armadillos. Twenty-three of the private reserves and farms visited joined the network. Their owners and workers were trained in the use of camera traps to monitor armadillo populations (Table 3). They also received a calendar in which they could record sightings of armadillo species on their lands. The Friends of the Armadillos network currently covers an area of $500 \mathrm{~km}^{2}$, in which armadillos are now effectively protected from poaching, and are monitored by local people (Fig. 1).

\section{Education and raising awareness}

The education component included a variety of strategies to reach various target groups (Table 4). It included, among others, educational activities in 18 schools (Table 4). Three eco-clubs were initiated as a result of the interest shown by many schoolchildren. One of these developed an eco-trail called the path of the armadillo, with five stations representing the five ecosystems these animals inhabit, to raise awareness among their peers and neighbouring educational institutions. Another eco-club participated in the annual town parade, bearing handcrafted lanterns with armadillo reliefs and banners with messages about environmental conservation, and another involved the children of employees of Oleoducto de los Llanos Orientales in Bogotá. Talks were also held at universities in the Llanos as well as in Bogotá to raise awareness of armadillos and build capacity among students and professors (Table 3).

A 15-minute documentary was filmed to raise awareness of armadillos and their conservation (Table 4; Fundación Omacha, 2013). It included interviews with local people, researchers and authorities. The documentary was shown during regional meetings and workshops, as well as at universities, schools, and offices of the environmental authorities.

Two drawing books for children (Bernal-Neira \& CruzAntía, 2013; Morales Betancourt, 2015) and books for various audiences (Rodríguez et al., 2013a; Trujillo \& Superina, 2013) were published and distributed with the purpose of raising awareness among schoolchildren and the general public (Table 4). They were also made available on various websites; e.g. those of Fundación Omacha (2012) and the IUCN SSC Anteater, Sloth \& Armadillo Specialist Group (2010). Based on the book by Trujillo \& Superina (2013), an e-book was developed to convey information on armadillos interactively (Superina et al., 2016).

Flyers, pins, toy armadillos and eco-friendly cotton bags with the logo of the Armadillo Conservation Programme were distributed to the general public, both in schools and towns of the Llanos and in large cities, as a general marketing strategy to position armadillos as flagship species of the Llanos. Twenty-two local bakeries distributed paper bags printed with the programme logo to their customers. 


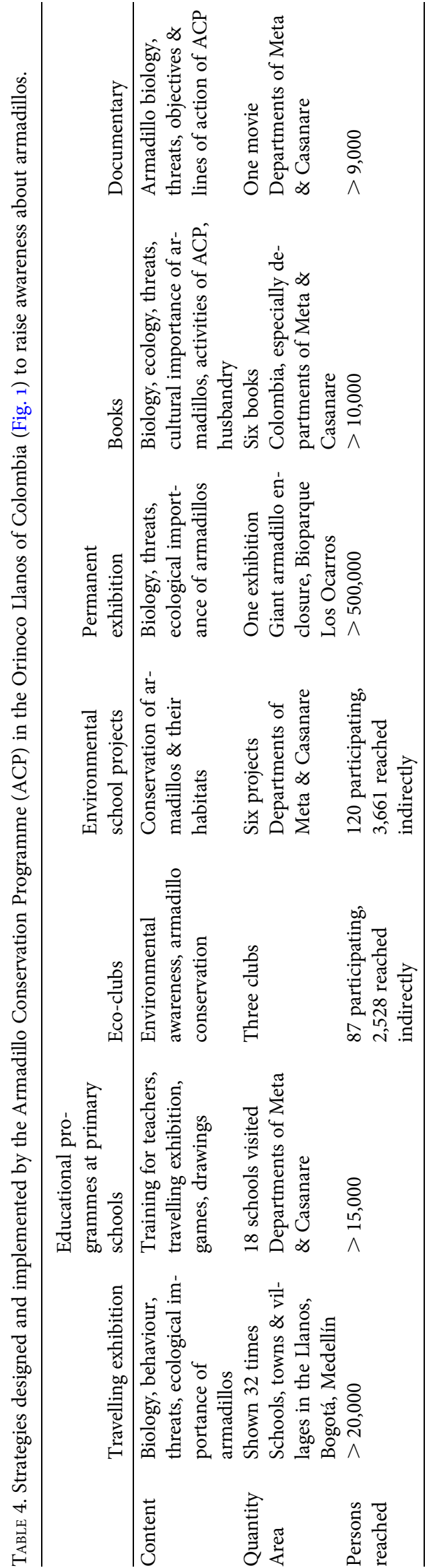

\section{Armadillo husbandry and ex situ conservation}

Four private breeding and rehabilitation facilities were established to host confiscated armadillos. Their purpose was to rehabilitate injured armadillos, establish a breeding programme, perform basic research on armadillo husbandry, and raise awareness among local communities. Community leaders committed to the conservation of armadillos administered the private facilities. They were visited regularly to monitor the well-being of the animals, and to train the community leaders and their families (Table 3 ). Specialized veterinarians of the Armadillo Conservation Programme provided veterinary care. Bioparque Los Ocarros was the main focal point for receiving injured armadillos, and it was visited on a regular basis to train staff (Table 3). The husbandry conditions of all armadillo species kept at Bioparque Los Ocarros were revised, with improvements made to the enclosures, diets and veterinary care.

The most frequently kept species was $D$. sabanicola, followed by D. novemcinctus, C. unicinctus and P. maximus. The latter was kept only at Bioparque Los Ocarros. Eight litters of $D$. sabanicola and $D$. novemcinctus were born in two private breeding facilities and at Bioparque Los Ocarros. In 2015 two D. novemcinctus and 10 D. sabanicola were released in a private reserve participating in the Friends of the Armadillos programme.

Ex situ research was conducted at the Armadillo Conservation Programme's breeding facilities. It was targeted at gathering basic data on armadillos under human care and improving the conditions in which they are kept. One grantee performed a health evaluation of armadillos maintained under human care (Melo-Restrepo et al., 2013). The effect of environmental enrichment on the behavioural response of armadillos under human care was assessed as part of an undergraduate thesis funded by the Armadillo Conservation Programme (Cortés Duarte et al., 2016). The first ethogram for captive armadillos was developed as a result of this study (Cortés et al., 2015).

A manual on the maintenance and rehabilitation of armadillos was also developed, to provide the environmental authorities and zoo and wildlife veterinarians with practical information about handling, examining, transporting, treating, rehabilitating and reintroducing armadillos (Table 4; Superina et al., 2014a). In addition to providing them with the handbook, talks were held to train staff of the National Police of Colombia and environmental authorities in the appropriate handling and care of armadillos.

\section{Discussion}

Evaluations of the success of conservation projects are often based on the perceptions of initiators or other stakeholders rather than on quantitative indicators (Chapman et al., 2016), and we do the same here. Subjectively, we consider 
the Armadillo Conservation Programme to be successful, but it is clear that we need to ensure its sustainability over time and collect additional data to measure its accomplishments quantitatively.

One major achievement of the programme is that it has raised awareness of armadillos. The attention given to them by the authorities and local communities in Colombia was virtually non-existent before the inception of the programme. Local knowledge of the cultural value of armadillos, or even of the existence of these species, was being lost, thus further jeopardizing their long-term conservation (Trujillo \& Superina, 2013). We have reversed this lack of attention by engaging stakeholders in all stages of programme planning and execution. By combining several approaches, we also maximized the likelihood of a successful outcome for the conservation programme (Chapman et al., 2016; Nilsson et al., 2016).

The development of the first joint action plan between two environmental authorities of Colombia, Corporinoquia and Cormacarena, is an important advance. Colombian environmental authorities traditionally define their species conservation strategies independently, even though species distributions often encompass several jurisdictions. National conservation strategies exist for some taxa, including Xenarthra (Ministerio de Ambiente y Desarrollo Sostenible, 2016), but they are formulated relatively broadly and do not take into account local problems and needs. Our approach is facilitating the implementation of conservation strategies throughout the entire Orinoco region of Colombia, where armadillos are subjected to similar threats. However, the mere existence of an action plan does not guarantee that it will be implemented, although it is a precondition for other conservation actions (Luther et al., 2016). Objectives pertaining to all seven lines of action of the Armadillo Action Plan have been addressed or were being implemented at the time of writing. The fact that we established armadillo breeding facilities at an early stage of the programme, thus addressing one of the main concerns of the authorities, probably helped keep them interested and actively involved.

Education is a key element of the Armadillo Conservation Programme. To date, our education programmes, awareness campaigns, publications and marketing strategies have reached $>30$,000 people of various ages, plus an estimated 500,000 visitors to Bioparque Los Ocarros who saw the permanent exhibition on armadillos (Table 4). Through these activities we were able to position armadillos as a non-traditional flagship species (sensu Entwistle, 2000) of the Llanos.

In addition to providing effective protection in an area of $500 \mathrm{~km}^{2}$, the Friends of the Armadillos initiative increased the interest of local people in biodiversity conservation. Although camera-trap monitoring was implemented by members of the local community and could lead some of them to perform independent research projects (Garnett et al., 2009), other activities did not lead to the expected results. The calendars that were distributed to the owners and inhabitants of private farms for the purpose of recording armadillo sightings had a low response rate, mainly because of the large turnover in farm employees.

Some restaurants were not interested in the 'Restaurants free of wild meat' label because they did not want to lose income from the sale of wild meat. For those who adhered, we perceived a certain relief because they were given a good reason to abandon an illegal activity. The combination of our various awareness campaigns and the implementation of this label have already led to positive results. In Meta department there has been a decrease in the number of armadillos and the amount of armadillo meat confiscated since 2012, in contrast to lowland pacas, which are not the focus of any conservation programme (C. Parra, Cormacarena, pers. comm.). This is probably related to greater awareness among the public as well as increased controls by the authorities, but we cannot entirely exclude the possibility that the lower rates of confiscation of armadillos are, at least in part, related to a reduction in abundance.

It is too soon to see an improvement in the conservation status of our target species as a result of our actions, even at the national level, as this requires, on average, c. 16 years (Young et al., 2014). However, given the scarcity of field studies on armadillos in Colombia prior to the initiation of the Armadillo Conservation Programme, the collection of scientific data that facilitate a more realistic assessment of the conservation status of the target species is an important accomplishment. Dasypus sabanicola was reassessed and recategorized from Least Concern to Near Threatened on the IUCN Red List (Superina et al., 2014c) based on data collected by the programme. Our observations reinforce the importance of preserving natural savannahs to protect this small armadillo. Dasypus kappleri, categorized as Least Concern on the IUCN Red List (Anacleto et al., 2014) and Not Evaluated on the national red list (Rodríguez-Mahecha et al., 2006), was the least frequently observed and reported species. As it is known to occur exclusively in forested areas, it may be as vulnerable to ongoing land-use change as P. maximus, and could therefore be threatened locally. Additional studies specifically targeted at this species are needed urgently, to assess its conservation status. Our findings indicate a requirement for the conservation of large, connected forest patches to prevent the local extinction of D. kappleri and P. maximus.

Habitat transformation in the Llanos cannot be halted because the expansion of agroindustrial activities in this area is promoted by state policies (Romero-Ruiz et al., 2012). Increasing the number of private protected areas may be an option, especially as they can be established more quickly than new national parks, and there has been a sustained increase in the number of private protected 
areas since 2006 (F. Trujillo, unpubl. data). Our future efforts will target the inclusion of additional private reserves in our Friends of the Armadillos programme. In parallel, we will need to seek ways to allow agroindustrial activities and armadillos to coexist, as has been done with bats and agaves in Mexico (Trejo-Salazar et al., 2016).

To date, the in situ and ex situ research performed or supported by the Armadillo Conservation Programme has led to two undergraduate theses and five field-based scientific publications (Aya-Cuero et al., 2015, 2017; Cortés et al., 2015; Aya-Cuero, 2016; Cortés Duarte et al., 2016), with other publications in preparation. Additional scientific data have been included in books (Trujillo \& Superina, 2013; Superina et al., 2014a) or presented at congresses (Melo-Restrepo et al., 2013; Díaz et al., 2015). The data produced by the Armadillo Conservation Programme thus already exceeds the field data on this group in Colombia over the previous 4 centuries (Superina et al., 2014b). In addition, the programme has broken a vicious circle that we noticed when we did not receive sufficient grant applications to distribute the funds available for armadillo research: because no established researchers or university lecturers were working with armadillos, students were not encouraged to do their undergraduate research on these animals. We counteracted this by giving talks at universities and offering specific training and mentorship to interested students and researchers. One of our former undergraduate students plans to continue working with armadillos, and the other was hired by the Armadillo Conservation Programme after she concluded her thesis. Another grantee plans to do her Master's research on armadillos. The university professors who were involved as advisors or co-advisors of these undergraduate projects expressed their interest in training future students in armadillo research, which will hopefully lead to an increase in the number of professionals dedicated to this taxon. In summary, this review of the Armadillo Conservation Programme demonstrates that passionate advocates for inconspicuous and poorly known species can bring about significant change.

Acknowledgements We are grateful to all participants and supporters of the Armadillo Conservation Programme for their enthusiasm and hard work, and to Oleoducto de los Llanos Orientales for their generous financial support. This study is part of the Conservation and Management Programme for the Armadillos of the Llanos of Colombia, established by Oleoducto de los Llanos Orientales, Cormacarena, Corporinoquia, Corpometa, Bioparque Los Ocarros, and Fundación Omacha under cooperation agreement PEDGE 1.4.8.1.13.002.

Author contributions Data compilation and analysis, writing: MS, ACD, FT.

Conflicts of interest None.
Ethical standards All authors abided by the Oryx Code of Conduct. The project followed the guidelines of the American Society of Mammalogists (Sikes et al., 2011).

\section{References}

Anacleto, T.C.S., Arteaga, M., Superina, M. \& Abba, A.M. (2014) Dasypus kappleri. In The IUCN Red List of Threatened Species 2014: e.T6289A47440608. Http://dx.doi.org/10.2305/IUCN.UK.2014-1. RLTS.T6289A47440608.en [accessed 11 August 2016].

Aristizábal, D., Baquero, J. \& Leal, D. (2000) Manejo eficiente de variedades mejoradas de arroz en los llanos orientales. Boletín Técnico Corpoica, Villavicencio, 21, 1-52.

Aya-Cuero, C. (2016) Transporte de material vegetal por el armadillo espuelón Dasypus kappleri Krauss, 1862 para la construcción de nido en un bosque de galería de los Llanos Orientales de Colombia. Edentata, 17, 57-60.

Aya-Cuero, C., Superina, M. \& Rodríguez-Bolaños, A. (2015) Primeros registros de crías de ocarro (Priodontes maximus Kerr, 1792) en Colombia. Edentata, 16, 57-64.

Aya-Cuero, C., Rodríguez-Bolaños, A. \& Superina, M. (2017) Population density, activity patterns, and ecological importance of giant armadillos (Priodontes maximus) in Colombia. Journal of Mammalogy, 98, 770-778.

Bayona, M. (2012) La nueva Colombia: entre la Orinoquia y la Amazonia el país se juega el futuro de sus próximos 50 años: ¿estaremos a la altura de este desafío? Revista Semana, Bogotá, Colombia.

Bernal-Neira, I. \& Cruz-Antía, D. (2013) Armandillo y los armadillos de mi Llano. Fundación Omacha, ODL, Cormacarena, Corporinoquia, Corpometa, and Bioparque Los Ocarros, Bogotá, Colombia.

Chapman, C.A., Deluycker, A., Reyna-Hurtado, R.A., Serio-Silva, J.C., Smith, T.B., Strier, K.B. \& Goldberg, T.L. (2016) Safeguarding biodiversity: what is perceived as working, according to the conservation community? Oryx, 50, 302-307.

Correa, H.D., Ruiz, S.L. \& Arévalo, L.M. (2006) Plan de acción en biodiversidad de la cuenca del Orinoco-Colombia / 2005-2015propuesta técnica. Corporinoquia, Cormacarena, Instituto Alexander von Humboldt, Unitrópico, Fundación Omacha, Fundación Horizonte Verde, Universidad Javeriana, Unillanos, WWF Colombia, and GTZ Colombia, Bogotá, Colombia.

Cortés, A., Superina, M. \& Trujillo, F. (2015) Etograma para tres especies de armadillos (Dasypus sabanicola, D. novemcinctus y Cabassous unicinctus) mantenidas en condiciones controladas en Villavicencio, Colombia. Edentata, 16, 1-10.

Cortés Duarte, A., Trujillo, F. \& Superina, M. (2016) Behavioral responses of three armadillo species (Mammalia: Xenarthra) to an environmental enrichment program in Villavicencio, Colombia. Zoo Biology, 35, 304-312.

CRECE (Centro de Estudios Regionales Cafeteros y Empresariales) (2010) Estudio sobre la competitividad del maíz y la soya en la altillanura colombiana. CRECE, Bogotá, Colombia.

Departamento Administrativo Nacional de Estadística (2017) Censo general 2005. Http://www.dane.gov.co/ [accessed 11 May 2017].

Díaz, C., Bogotá, Y., Caballero, S., Renzo, M. \& Guhl, F. (2015) Detección molecular de Trypanosoma cruzi en armadillos de cuatro departamentos de Colombia. Biomédica, 35, 92.

Dishington, J. (2007) La agroindustria de la palma de aceite y sus perspectivas en la región de la Orinoquia. In Memorias X cumbre de gobernadores y I de parlamentarios de la región amazo-orinoquia. Villavicencio, Colombia. 
Entwistle, A. (2000) Flagships for the future. Oryx, 34, 239-240. Fedearroz (2008) Censo arrocero llanos orientales 2008. Fedearroz, Bogotá, Colombia.

Fedepalma (2008) Informe de gestión 2007. Fedepalma, Bogotá, Colombia.

FundaCIÓN OMACHa (2013) Los arquitectos de la naturaleza: armadillos. Https://www.youtube.com/watch?v=TAZefTuuESQ [accessed 6 December 2017].

Fundación Omacha (2012) Fundación Omacha. Http://www. omacha.org [accessed 1 December 2017].

Garnett, S.T., Crowley, G.M., Hunter-Xenie, H., Kozanayi, W., Sithole, B., Palmer, C. et al. (2009) Transformative knowledge transfer through empowering and paying community researchers. Biotropica, 41, 571-577.

Garnett, S.T. \& Lindenmayer, D.B. (2011) Conservation science must engender hope to succeed. Trends in Ecology and Evolution, 26, $59-60$.

Hernández-Camacho, J. \& Sánchez, H. (1992) Biomas terrestres de Colombia. In La diversidad biológica de Iberoamérica (ed. G. Halffter), pp. 153-173. Acta Zoológica Mexicana, CYTED-D, Xalapa, Mexico.

Instituto Alexander von Humboldt (2009) Informe sobre el estado de la biodiversidad en Colombia 2007-2008: piedemonte orinoquense, sabanas y bosques asociados al norte del río Guaviare. Instituto Alexander von Humboldt, Bogotá, Colombia.

Instituto de Hidrología, Meteorología y Estudios Ambientales (2016) Sistema de monitoreo de bosques y carbono. IDEAM, Bogotá, Colombia. Http://ideam.gov.co/ [accessed 27 April 2016].

IUCN (2017) The IUCN Red List of Threatened Species v. 2017-1. Http:// www.iucnredlist.org/ [accessed 22 May 2017].

iUCN SSC Anteater, Sloth and Armadillo Specialist Group (2010) The IUCN SSC Anteater, Sloth and Armadillo Specialist Group. Http://www.xenarthrans.org [accessed 6 December 2017].

Lasso, C.A., Rial, A., Matallana, C., Ramírez, W., Señaris, J., Díaz-Pulido, A. et al. (2011) Biodiversidad de la Cuenca del Orinoco. II. Áreas prioritarias para la conservación y uso sostenible. Instituto de Investigación de Recursos Biológicos Alexander von Humboldt, Ministerio del Ambiente, Vivienda y Desarrollo Territorial, WWF Colombia, Fundación Omacha, Fundación La Salle de Ciencias Naturales, and Instituto de Estudios de la Orinoquia (Universidad Nacional de Colombia), Bogotá, Colombia.

Luther, D.A., Brooks, T.M., Butchart, S.H.M., Hayward, M.W., Kester, M.E., Lamoreux, J.F. \& Upgren, A. (2016) Determinants of bird conservation-action implementation and associated population trends of threatened species. Conservation Biology, 30 , $1338-1346$

Melo-Restrepo, J.S., Parra, C., Murillo-Pacheco, R. \& FernándeZ-Manrique, J. (2013) Contribución al conocimiento de los parámetros hematológicos en armadillo nueve bandas (Dasypus novemcinctus), en núcleos de reubicación de fauna silvestre en la orinoquia Colombiana (resumen). In Conferencia Interna en Medicina y Aprovechamiento de Fauna Silvestre Exótica y no Convencional (eds. J.B. Mesa \& N. Varela), pp. 56-57. Asociación de Veterinarios de Vida Silvestre, Bogotá, Colombia.

Ministerio de Ambiente y Desarrollo Sostenible (2016) Programa nacional para la conservación y uso sostenible de las especies del superorden Xenarthra presentes en Colombia. Plan de acción 2014-2023. Ministerio de Ambiente y Desarrollo Sostenible y Fundación AIUNAU, Bogotá, Colombia.

Morales Betancourt, D. (2015) La travesía de los cachicamos. Fundación Omacha, ODL, Cormacarena, Corporinoquia, Corpometa, and Bioparque Los Ocarros, Bogotá, Colombia.
Nilsson, D., Baxter, G., Butler, J.R.A. \& McAlpine, C.A. (2016) How do community-based conservation programs in developing countries change human behaviour? A realist synthesis. Biological Conservation, 200, 93-103.

Reed, M.S. (2008) Stakeholder participation for environmental management: a literature review. Biological Conservation, 141, 2417-2431.

RedFord, K.H. (1985) Food habits of armadillos (Xenarthra: Dasypodidae). In The Evolution and Ecology of Armadillos, Sloths, and Vermilinguas (ed. G.G. Montgomery), pp. 429-437. Smithsonian Institution Press, Washington, DC, USA.

Rodríguez, P., Superina, M., Cruz-Antía, D. \& Trujillo, F. (2013a) Los armadillos de los Llanos Orientales de Colombia. ODL S.A., Fundación Omacha, Corporinoquia, Cormacarena, Corpometa, Bioparque Los Ocarros, Bogotá, Colombia.

Rodríguez, P., Trujillo, F. \& Cruz-Antía, D. (2013b) Evaluación biológica de los armadillos. In Armadillos de los Llanos Orientales (eds F. Trujillo \& M. Superina), pp. 114-123. ODL, Fundación Omacha, Cormacarena, Corporinoquia, and Bioparque Los Ocarros, Bogotá, Colombia.

Rodríguez-Mahecha, J.V., Alberico, M., Trujillo, F. \& Jorgenson, J. (2006) Libro Rojo de los mamíferos de Colombia. Serie Libros Rojos de especies amenazadas de Colombia. Conservación Internacional \& Ministerio de Ambiente, Vivienda y Desarrollo Territorial, Bogotá, Colombia.

Romero-Ruiz, M.H., Flantua, S.G.A., Tansey, K. \& Berrio, J.C. (2012) Landscape transformations in savannas of northern South America: land use/cover changes since 1987 in the Llanos Orientales of Colombia. Applied Geography, 32, 766-776.

SÁnCHeZ, L. (2007) Caracterización de los grupos humanos rurales de la cuenca hidrográfica del Orinoco en Colombia. Instituto de Investigación de Recursos Biológicos Alexander von Humboldt, Bogotá, Colombia.

Sikes, R.S., Gannon, W.L. \& Animal Care and Use Committee of the American Society of Mammalogists (2011) Guidelines of the American Society of Mammalogists for the use of wild mammals in research. Journal of Mammalogy 92, 235-253.

Superina, M., Brieva, R.C., Aguilar, R.F. \& Trujillo, F. (2014a) Manual de mantenimiento y rehabilitación de armadillos. Fundación Omacha, ODL, Cormacarena, Corporinoquia, Corpometa and Bioparque Los Ocarros, Bogotá, Colombia.

Superina, M., Pagnutti, N. \& Abba, A.M. (2014b) What do we know about armadillos? An analysis of four centuries of knowledge about a group of South American mammals, with emphasis on their conservation. Mammal Review, 44, 69-80.

Superina, M., Trujillo, F., Arteaga, M. \& Abba, A.M. (2014c) Dasypus sabanicola. In The IUCN Red List of Threatened Species 2014: e.T6292A47441316. Http://www.iucnredlist.org/details/6292/o [accessed 11 August 2016].

Superina, M., Trujillo, F., Mosquera, F., Combariza, R. \& PARra, C.A. (2014d) Plan de acción para la conservación de los armadillos de los Llanos Orientales. Cormacarena, Corporinoquia, ODL, and Fundación Omacha, Bogotá, Colombia.

Superina, M., Trujillo, F. \& Cortés, A. (2016) Armadillos de los Llanos Orientales. E-book version for OSX. Fundación Omacha, Bogotá, Colombia.

Sutherland, W.J. (2000) The Conservation Handbook: Research, Management and Policy. Blackwell Publishing, Oxford, UK.

Trejo-Salazar, R.E., Eguiarte, L.E., Suro-Piñera, D. \& Medellín, R.A. (2016) Save our bats, save our tequila: industry and science join forces to help bats and agaves. Natural Areas Journal, 36 , 523-530. 
Trujillo, F. \& Superina, M. (2013) Armadillos de los Llanos Orientales. ODL, Fundación Omacha, Cormacarena, Corporinoquia, and Bioparque Los Ocarros, Bogotá, Colombia. Wickramasinghe, L.P., Harris, S., Jones, G. \& Jennings, N.V. (2004) Abundance and species richness of nocturnal insects on organic and conventional farms: effects of agricultural intensification on bat foraging. Conservation Biology, 18, 1283-1292.

Young, R.P., Hudson, M.A., Terry, A.M.R., Jones, C.G., Lewis, R. E., Tатауан, V. et al. (2014) Accounting for conservation using the IUCN Red List Index to evaluate the impact of a conservation organization. Biological Conservation, 180, 84-96. 